\title{
THE DUTY OF CARE AND THE BUSINESS JUDGMENT RULE: A CASE STUDY IN LEGAL TRANSPLANTS AND LOCAL NARRATIVES
}

\author{
Carsten Gerner-Beuerle*
}

\section{Introduction}

The duty of care and, increasingly, the business judgment rule are common features of any developed system of corporate law. The duty of care is one of the oldest legal institutions to impose constraints on the behaviour of corporate directors (and more generally persons acting in various commercial relationships). In an early form, it can be found in Roman law on the societas, which required each partner to exercise the care that they were accustomed to display in their own affairs in matters of business management. ${ }^{1}$ It is also a near-universal rule; it exists in one form or another in virtually every jurisdiction. ${ }^{2}$ This is unsurprising, given that the duty of care is concerned with a central economic problem to which the use of the corporate form gives rise: the managerial agency problem. This economic problem exists whenever management authority is delegated and has prompted regulatory intervention around the world, irrespective of legal tradition or form of market economy.

\footnotetext{
*Professor of Commercial Law, University College London, email: c.gerner@ucl.ac.uk.

${ }^{1}$ Reinhard Zimmermann, The Law of Obligations: Roman Foundations of the Civilian TRAdition 46165 (1996).

${ }^{2}$ For a detailed comparison of the duty of care in the United States and the United Kingdom, see DAVID KeRSHAW, The Foundations of ANGlo-American Corporate Fiduciary LAW 135-281 (2018). For further selected common law jurisdictions, see Jennifer G. Hill, Evolving directors' duties in the common law world in RESEARCH HANDBOOK ON DiRECTORS' Duties 3 (Adolfo Paolini ed., 2014). For European civil law countries, see Carsten Gerner-Beuerle \& Edmund-Philipp Schuster, Mapping Directors' Duties: The European Landscape in BOARDS of Directors in European Companies 13, 14-23 (Hanne Birkmose, Mette Neville \& Karsten Engsig Sørensen eds., 2013). For China, see Guangdong Xu et al., Directors' Duties in China, 14 EBOR 57. For Japan, see Hideki Kanda \& Curtis J. Milhaupt, Re-Examining Legal Transplants: The Director's Fiduciary Duty in Japanese Corporate Law, 51 AM. J. CoMP. L. 887. Other broad comparative studies include Bernard S. Black et al., Comparative Analysis on Legal Regulation of the Liability of Members of the Board of Directors and Executive Organs of Companies, ECGI - Law Working Paper Series 103/2008; PAUl DAVIES ET AL. (EDS.), CoRPORATE Boards in Law and Practice (2013); and Andreas M. Fleckner \& Klaus J. Hopt (eds.), Comparative CORPORATE GOVERNANCE: A FUNCTIONAL AND INTERNATIONAL ANALYSIS (2013).
} 
The duty of care has given rise to a "judicial offshoot" that qualifies the enforceability of breaches of the duty of care and has resulted, in particular in the United States, in a clear separation of a standard of conduct and a standard of review: the business judgment rule. The business judgment rule gives legal expression to the idea that questions of business judgment are best left to the honest decision of the directors. Courts are not well placed to substitute their own discretion for that of the directors, since they typically lack the necessary expertise and act with the benefit of hindsight. ${ }^{3}$ Allowing courts to fully review business decisions adopted in good faith and without a conflict of interest could give rise to the risk of false positives: instances where courts might identify a breach of the duty, even though the decisions of directors, assessed from an ex-ante perspective under conditions of uncertainty about the future, were duty-compliant. Since this economic problem exists in all jurisdictions, legal systems can be expected to have developed solutions that restrict the liability of directors. ${ }^{4}$ One such solution is the business judgment rule, ${ }^{5}$ which has diffused increasingly widely over the last few decades and can now be found, for example, in eight European countries that all belong to the civil law tradition. ${ }^{6}$

Both the duty of care and the business judgment rule exhibit remarkable consistency across jurisdictions. Formulations of the two rules vary in details, but the basic contours of the duty of care and the business judgment rule (where it has been adopted) are similar. This may be the result of conscious borrowing, especially in the case of the business judgment rule, or independent decisions driven by the realization that it was eminently reasonable to impose an expectation to act with due care on persons dealing with other people's money, or a combination of both. Whatever the reason may be, the question arises whether legal institutions that exist in two or more jurisdictions and are formulated in such similar terms as the duty of care and the business judgment rule, operate similarly, as one would perhaps expect, or, if they do not, why they fail to produce similar outcomes.

\footnotetext{
${ }^{3}$ For an overview of the historical development of the business judgment rule, see KERSHAw, supra note 2, 6892.

${ }^{4}$ It can be shown that restricting liability for breaches of the duty of care is efficient, see Holger Spamann, Monetary Liability for Breach of the Duty of Care?, 8 JLA 337.

${ }^{5}$ Functionally equivalent solutions exist, as we will see in section 2.

${ }^{6}$ These eight countries are Austria, the Czech Republic, Croatia, Germany, Greece, Portugal, Spain and Romania. See Luis Hernando Cebría, The Spanish and the European Codification of the Business Judgment Rule, 15 ECFR 41 (2018).
} 
These questions are taken up in the two main parts of this chapter. The first part, section 2, is a mapping exercise that shows the extent to which the duty of care and the business judgment rule, or functional equivalents, have diffused and converged in selected jurisdictions. The second part, section 3 , challenges the degree of convergence that section 2 has, ostensibly, illustrated. This section claims that the inherent meaning of transplanted legal institutions is not necessarily transferred together with the text of the norm, and perhaps will only rarely be transplanted together with it, since meaning is context-specific and a function of a variety of non-legal factors, such as a certain understanding of the benefits and risks of different socioeconomic systems that is prevalent in an economy. ${ }^{7}$ In making this claim, I draw on prior research that has highlighted that the content of norms, even norms that are ostensibly welldefined, will often be open-ended in the sense that a "multiplicity of meaning" 8 can attach to one norm. This multiplicity of meaning is culturally determined, ${ }^{9}$ it centres on "narrative traditions", ${ }^{10}$ with judges being in a privileged position to control and shape these narratives. ${ }^{11}$

Section 3 focuses on the Delaware business judgment rule and its German counterpart in order to substantiate the claim that narratives influence the prevalent local understanding of a transplanted legal institution, and to show that they may, in some cases, influence the understanding of a rule to an extent that two similarly formulated rules lead to diametrically opposed outcomes in comparable cases. These two jurisdictions are often held out as paradigmatic examples of distinct legal traditions and models of the market economy, falling on different sides of the divide between liberal and coordinated market economies proposed by the varieties of capitalism literature. ${ }^{12}$ It has been pointed out that the way market actors

\footnotetext{
${ }^{7}$ Whether the context-specific nature of meaning leads to the "impossibility of legal transplants", as claimed by Pierre Legrand, The Impossibility of 'Legal Transplants', 4 MJ 111 (1997), may remain an open question. The goal of this chapter is less ambitious, namely to examine whether the transplantation of two particular legal institutions (the duty of care and the business judgment rule) has taken place not only in a formal, but also a substantive sense of the word in a particular set of countries.

${ }^{8}$ Robert M. Cover, Nomos and Narrative, 97 HARV. L. REV. 4, 16 (1983).

${ }^{9} I d$. at 11 .

${ }^{10} \mathrm{Id}$. at 17 .

${ }^{11}$ Cover speaks of judges as "one source of privileged precept articulation", id. at 17, fn. 44. See also id. at 40.

${ }^{12}$ In a liberal market economy, coordination takes place primarily via hierarchies within firms and competitive market arrangements between firms. In a coordinated market economy, in contrast, economic actors rely more frequently on collaborative non-market relationships to coordinate their activities, for example relational networks or collectivist strategies implemented through organized associations, such as trade unions, see Peter A. Hall \& David Soskice, An Introduction to Varieties of Capitalism in VARIETIES OF CAPITALISM: THE InSTITUTIONAL Foundations of Comparative Advantage 1, 8 (Peter A. Hall \& David Soskice eds., 2001). Britain, the United States and many other common law countries are typically referred to as liberal market economies, Germany, Japan, Switzerland and other countries in the German and Scandinavian legal traditions as coordinated market
} 
coordinate their activities, and thus the type of market economy that arises, is a function of the shared experiences of these actors and the cultural norms that are prevalent in a society. ${ }^{13}$ The concept of narratives, as it is used in this chapter, is closely related to such cultural determinants. Where narratives differ across types of the market economy, it is reasonable to assume that they also shape legal institutions differently. At the same time, in spite of clearly distinct approaches to ordering the market economy, the duty of care and the business judgment rule are largely identical in Delaware and Germany, as will be shown in section 2 . The two jurisdictions, therefore, constitute an ideal case to test the impact of local narratives on the codified law.

\section{Diffusion of the duty of care and the business judgment rule}

\subsection{Origins}

The common law duty of care has its origins in $18^{\text {th }}$ and $19^{\text {th }}$ century trust law and the law of bailment, from which it was adapted to corporate directors. ${ }^{14}$ Early English case law concerning the duties of corporate directors emphasised that directors were "in the position of trustee" or "quasi trustees". ${ }^{15}$ As such, they were required "to use all the ordinary prudence that can be properly and legitimately expected from any person in the conduct of the affairs of the world". ${ }^{16}$ In the development of the duty of care in the United States, it has been shown that the law of bailment was more influential than trust law, a difference that has been associated with differences in the conceptualization of companies incorporated by registration. In the United States, the general incorporation statutes of the $19^{\text {th }}$ century were intended to open up access to the corporate form and make it unnecessary to petition state legislatures for a corporate charter. Registered companies could therefore be seen as a continuation of chartered companies, and there was no question that both were the legal owners of the assets devoted to the business

economies, and several Mediterranean countries, including France, Italy and Spain, are regarded as occupying an ambiguous position, $i d$. at 19-21.

${ }^{13} I d$. at $12-14$.

${ }^{14}$ KERSHAW, supra note 2, 229-63.

${ }^{15}$ Re Exchange Banking Co (Flitcroft's Case) (1882) 21 Ch. D. 519, 534-35. But see also In Re City Equitable Fire Insurance Company [1925] Ch. 407, 426, where Romer J. adopted a more nuanced view eschewing direct analogies. For a careful analysis of the extent to which courts relied on analogies to trust law and the law of bailment, see KERSHAW, supra note 2, 230-35.

${ }^{16}$ Overend \& Gurney v Gibb (1871-72) L.R. 5 H.L. 480, 494. 
enterprise. In Britain, in contrast, incorporation by registration was introduced to remedy the defects to which the widespread use of so-called deed-of-settlement companies had given rise, which were based on partnership law and hence were not separate legal entities that owned the assets of the business. ${ }^{17}$ The law of bailment was a more natural analogy in the United States, since a bailee, just as a director, was entrusted with the management of assets owned by other persons, while there was an actual trustee in a deed-of-settlement company, who was the legal owner of the association's property. ${ }^{18}$ These conceptual differences had implications for the standard of care applicable to directors, ${ }^{19}$ but not the fact that directors, as fiduciaries akin to either bailees or trustees, were subject to a duty of care. In the early duty of care case Briggs $v$. Spaulding, for example, the US Supreme Court held that directors, "as mandataries ... are ... bound to apply ordinary skill and diligence". ${ }^{20}$

In their reliance on analogies with agents or bailees, ${ }^{21}$ the early approach in the United States resembles the origins of the duty of care in civil law countries. The first European piece of legislation to develop a general set of rules governing stock corporations and other business associations, the French Code de Commerce of 1807, described the directors as mandataries who were only responsible for carrying out their contractually agreed duties: "Les administrateurs ne sont responsables que de l'exécution du mandat qu'ils ont reçu." 22 In addition to France, the Code de Commerce applied in some western states of the former Holy Roman Empire from 1806-1813 (the so-called Confederation of the Rhine). It also influenced the first Germany-wide codification of stock corporation law, the General German Commercial Code of 1861, and the corporate laws of other continental European states, for example Portugal and Spain. These jurisdictions drew on agency law to require directors to discharge their duties with appropriate care, but had nothing to say about duties not conferred on the directors as part of their mandate. ${ }^{23}$ Early European statutes, accordingly, focused only on the

\footnotetext{
${ }^{17}$ KERSHAW, supra note 2, 176, 233-35.

${ }^{18} I d$. at 234 .

${ }^{19}$ Early case law in the United States was pulled in the direction of a gross negligence standard, arguably informed by the bailment analogy, since the standard of care pursuant to the law of bailment was gross negligence if the bailee acted gratuitously. See the references $i d$. at 143-59, 174-96.

20141 U.S. 132, 148 (1891), quoting Spering's Appeal, 71 Pa. 11, 21 (1872).

${ }^{21} I d$.

${ }^{22}$ Code de Commerce, Art 32.

${ }^{23}$ For a contemporary comparative overview, see ACHILLES RENAUD, DAS RECHT DER ACTIENGESELLSCHAFTEN 538-39 (1863).
} 
transgression of the mandate by a director or the failure to comply with the law and the articles, but did not describe the position of directors in terms of duties. They did not recognize obligations that existed by virtue of the appointment to a position of power and were separate from the contractually established obligations governing directorial behavior, and hence did not regard directors as being subject to a general duty of care (or indeed a duty of loyalty ${ }^{24}$ ). ${ }^{25}$

The prevalent civil law approach changed over time, as commentators and policy makers came to realize that a formulation of the duty of care that focused on the position of directors within the corporate hierarchy, rather than their contractual obligations, was necessary to capture certain pathologies of the corporate form. ${ }^{26}$ For example, a sweeping reform of German stock corporation law of $1884,{ }^{27}$ which was adopted in response to widespread corporate misconduct that had led to the first major stock exchange crash in German history, replaced the contractual focus of the formulation of directorial behavioral expectations with a positional focus. The General Commercial Code, as revised in 1884, provided that, "in managing the corporation, the members of the management board have to exercise the care of a diligent businessman". ${ }^{28}$ The provision has not been amended substantially since 1884, and the current Stock Corporation Act requires directors to "exercise the care of a diligent and conscientious manager in managing the company." 29 A similar shift away from a contractual understanding of directors' duties occurred in other continental European systems at different times, for example

\footnotetext{
${ }^{24}$ The narrow conceptualization of the obligations of directors proved particularly obstructive to the development of the duty of loyalty. Many continental European jurisdictions operated for a long time (and to some degree still operate) with fragmentary rules, rather than an all-encompassing behavioural standard, to address conflicts of interest, see CARSTEn Gerner-Beuerle \& Michael Schillig, Comparative Company Law 508, 565-69, 57475 (2019).

${ }^{25}$ See, e.g., Allgemeines Deutsches HandelsgesetzBuch 1861 (ADHGB) [General German Commercial Code], Art 241(2), providing that 'members of the management board who exceed the limits of their mandate or act in contravention of the provisions of this title [of the Commercial Code] or the articles of association are personally and jointly liable for the damage thus caused'.

${ }^{26}$ See, for example, the criticism of the General German Commercial Code of 1861 by RENAUD, supra note 23, 537, who argued that the scope and content of the duties of directors should be determined by the law, articles, resolutions of the general meeting, and what was inherent in their position as a director.

${ }^{27}$ GeSeTZ, BetrefFend die Kommanditgesellschaften auf AKTIEN UND DiE AKTIENGeSELLSCHAFten [Act concerning limited partnerships by shares and joint stock corporations] of 18 July 1884, RGBl. 1884, p. 123.

28 ADHGB, Art 241(2) (emphasis by author). The standard of the "diligent businessman" is translated from "ordentlicher Geschäftsmann". The same standard of care applied to members of the supervisory board, ADHGB, $\S 226(1)$.

${ }^{29}$ AKtiEngesetz (AKTG) 1965 [Stock Corporation Act 1965], BGBL. I, p. 1089, § 93(1). The slightly different formulation in comparison with the ADHGB of 1884, which includes the word "conscientious", was not intended to modify the applicable standard of care, see Marcus Lutter, Der Aufsichtsrat im Wandel der Zeit - von seinen Anfängen bis heute in AKTIENRECHT IM WANDEL II: GRUNDSATZFRAGEN DES AKTIENRECHTS 389, 407 (Walter Bayer \& Mathias Habersack eds., 2007).
} 
in France in the 1940s. ${ }^{30}$ Some remnants of the tripartite reference to the director's mandate (contract), the articles of association, and corporate law as sources of directorial obligations is nevertheless still discernible in the formulation of the duties of directors in some civil law jurisdictions. The relevant provision of the French Commercial Code, for example, bears little resemblance to the duty of care of Anglo-American provenance: "The directors ... shall be individually or jointly and severally liable to the company or third parties either for infringements of the laws or regulations applicable to public limited companies, or for breaches of the memorandum and articles of association, or for management mistakes." 31

\subsection{Standard of care}

In spite of the different genesis of the duty of care and certain remaining differences in the formulation of the codified duties, the standard of care across both common and civil law countries is remarkably similar. Legal systems typically use variations of the "ordinary man" or "ordinary businessman" to describe the standard of care expected of directors. In the leading English duty of care case until the codification of the duties in 2006, City Equitable Fire Insurance Company, ${ }^{32}$ Romer J held that directors were expected to act with "reasonable care", which was "to be measured by the care an ordinary man might be expected to take in the circumstances on his own behalf". ${ }^{33}$ The English common law standard, thus, was ostensibly an objective standard. However, City Equitable infused this objective standard with subjective elements distilled from earlier case law. Importantly, Romer J stated that "[a] director need not exhibit in the performance of his duties a greater degree of skill than may reasonably be expected from a person of his knowledge and experience." 34 It was unclear how the reference to the defendant director's subjective attributes was to be reconciled with the objective benchmark and, in particular, whether lack of competence or experience was liable to reduce the standard of care below that of the reasonably ordinary businessman. ${ }^{35}$ The uncertainty was

\footnotetext{
30 Carsten Gerner-Beuerle, Philipp Paech \& Edmund Schuster, Study on Directors' Duties and Liability, ANNEX: Directors' Duties AND Liability IN France, p. A304 (2013), available at http://personal.lse.ac.uk/schustee/2013-study-reports_en.pdf.

${ }^{31}$ Code de COMMERCE [French Commercial Code], Art L225-251.

32 [1925] Ch. 407.

${ }^{33} I d$. at 428 .

${ }^{34} I d$. (emphasis by author).

${ }^{35}$ For an overview of the discussion and references, see GERNER-BEUERLE \& SCHILLIG, supra note 24, 477-78.
} 
resolved in the 1990s with two High Court judgments that established a dual objectivesubjective standard, which was later codified in section 174 of the Companies Act 2006. ${ }^{36}$ Pursuant to section 174, directors are required to "exercise reasonable care, skill and diligence", which is defined as "the care, skill and diligence that would be exercised by a reasonably diligent person with ... the general knowledge, skill and experience that may reasonably be expected of a person carrying out the functions carried out by the director in relation to the company, and ... the general knowledge, skill and experience that the director has." 37

Delaware law and many other common law and civil law jurisdictions have adopted a standard of conduct that closely conforms to the objective leg of the UK's dual standard. The Delaware Court of Chancery, in Re Walt Disney Co. Derivative Litigation, ${ }^{38}$ held that " $[\mathrm{t}]$ he fiduciary duty of due care requires that directors of a Delaware corporation 'use that amount of care which ordinarily careful and prudent men would use in similar circumstances,' and 'consider all material information reasonably available' in making business decisions". ${ }^{39}$ There is little difference between this formulation and the "care of a diligent and conscientious manager" under German law. ${ }^{40}$ In both jurisdictions, it is undisputed that the standard of care is objective, but varies with the circumstances, including the type of company and industry, the financial situation of the company, general market conditions, and the director's role and responsibilities within the corporate hierarchy. Furthermore, the requirement mentioned in Walt Disney that directors "consider all material information reasonably available" is almost identical to the expectation under the German Stock Corporation Act that they act based on "appropriate information", ${ }^{41}$ which has been held to mean that directors must avail themselves of all available information, provided the costs are not disproportionate to the benefits. ${ }^{42}$ As a final example from yet another legal tradition, we may consider the central provision of the French law on the public stock corporation concerning the liability of directors, which was already quoted above. ${ }^{43}$ According to this provision, directors are liable for so-called management

\footnotetext{
${ }^{36}$ Norman $v$ Theodore Goddard [1992] B.C.C. 14; Re D'Jan of London Ltd [1993] B.C.C. 646.

${ }^{37}$ UK COMPANIES ACT 2006, s. 174(2).

38907 A.2d 693 (Del. Ch. 2005).

${ }^{39} I d$. at 749.

${ }^{40}$ AKTG, § 93(1), sentence 1.

${ }^{41}$ AKTG, $\S 93(1)$, sentence 2.

${ }^{42}$ Gerald Spindler, $\S 93 \mathrm{AktG}$ in MÜNCHENER KommentaR ZUM AKTIENGESETZ, vol. 2 para. 55 (Wulf Goette, Mathias Habersack \& Susanne Kalss eds., 5th ed. 2019).

${ }^{43}$ Supra, text to note 31 .
} 
mistakes, in addition to breaches of the law and the memorandum and articles of association. What constitutes a management mistake is measured against the benchmark of the care that can reasonably be expected from a "prudent and diligent manager". ${ }^{44}$ Again, the precise behavioural expectations that are derived from this standard depend on the circumstances of the case, in particular the director's role in the company and the type of company. ${ }^{45}$ Thus, in all four jurisdictions reviewed briefly in this section, the formulation of the standard of care is largely interchangeable, in spite of the fact that these jurisdictions represent three distinct legal traditions that embody distinct approaches to ordering the market economy. ${ }^{46}$ This does not mean, of course, that the operation of the duty of care is interchangeable. We will come back to this point in section 3 below.

\subsection{Business judgment rule}

While a formal business judgment rule does not exist in many jurisdictions, the economic problem discussed above - the inefficiencies created by the full review of business judgments by a court with the benefit of hindsight and, possibly, without the necessary expertise and experience ${ }^{47}$ - has been addressed in some form by most legal systems. It is clear that courts were acutely aware of this problem early on in the development of the duty of care, as illustrated by the following quote from one of the leading English cases from the $19^{\text {th }}$ century, Overend \& Gurney $v$ Gibb: ${ }^{48}$

I think it would be a very fatal error in the verdict of any Court of justice to attempt to measure ... the amount of prudence that ought to be exercised by the amount of prudence which the judge himself might think, under similar circumstances, he should have exercised. I think it extremely likely that many a judge, or many a person versed by long experience in the affairs of mankind, as conducted in the mercantile world, will know that there is a great deal more trust, a great deal more speculation, and a great deal more readiness to confide in the probabilities of things, with regard to success in mercantile transactions,

\footnotetext{
${ }^{44}$ Cass. com., 30 March 2010 (Crédit Martiniquais), Revue des sociétés 2010, p. 304, note P. Le Cannu.

${ }^{45}$ Philippe Merle, Droit commercial: Societes commerciales (22nd ed. 2018), para. 458.

${ }^{46}$ See supra, note 12 and accompanying text.

${ }^{47}$ Supra, text to notes 3-5.

${ }^{48}$ Overend \& Gurney v Gibb (1871-72) L.R. 5 H.L. 480, 494-95.
} 
than there is on the part of those whose habits of life are entirely of a different character. It would be extremely wrong to import into the consideration of the case of a person acting as a mercantile agent in the purchase of a business concern, those principles of extreme caution which might dictate the course of one who is not at all inclined to invest his property in any ventures of such a hazardous character.

English courts have not formalised the considerations expressed in the above excerpt and delineated the boundaries of a director's business judgment, within which the courts will only exercise limited review. However, implicitly, they apply two distinct standards of care that have the effect of shielding a director's good faith business decisions from judicial review. The first is a good faith standard that applies to the content of a director's decision. Directors must act in what they consider, in good faith, to be in the best interest of the company. ${ }^{49}$ Good faith is analysed, in the absence of evidence of a director's actual state of mind, based on the reasons given for the challenged decision. While the case law is not entirely consistent and courts tend to ask whether a particular course of action was "reasonable", they also stress that the relevant test is subjective. It does not involve an assessment of whether the decision was, in the court's view, objectively in the best interest of the company. ${ }^{50}$ This implies that the test may be seen, more accurately, as a form of plausibility or rationality test. Courts will not second-guess a business decision that is supported by rational business reasons, in the sense of reasons that could have been regarded by at least some directors as suggesting that the decision was in the company's interest. ${ }^{51}$

The second standard is the one described in section 2.2 above, which is now laid down in section 174(2) Companies Act 2006: an ordinary due care standard that imposes heightened behavioural expectations if the director has particular knowledge, skill or expertise. The duty of care pursuant to section 174 Companies Act 2006 and the duty to act bona fide in the best interest of the company perform complementary functions. The former focuses on the process of decision-making. In arriving at a decision, directors are required to exercise the care, skill

\footnotetext{
${ }^{49}$ See, e.g., Re Smith \& Fawcett [1942] Ch 304. The duty to act in the best interest of the company is now codified in s. 172 Companies Act 2006.

${ }^{50}$ See, e.g. Regentcrest plc v Cohen [2001] B.C.C. 494 at 513-14.

${ }^{51}$ The standard has, accordingly, also been called the "any reasonable director" standard. See KERSHAw, supra note 2, at 47-58 for a careful and critical analysis of the terminology used by the courts and inconsistencies in the case law.
} 
and diligence that can be expected of a reasonably diligent person. The latter concerns the quality of the decision itself, which must promote the success of the company. ${ }^{52}$

This bifurcated standard is already discernible in Overend \& Gurney. The case concerned the acquisition of a banking business that had initially been very successful, but, at the time of the purchase, had incurred heavy losses and was balance sheet insolvent. The House of Lords found that the purchase itself, while risky and "imprudent", ${ }^{33}$ was not irrational. The directors had restructured the debts of the business and relied on its continuing good reputation in their expectation that the company would improve its financial situation and become again profitable. ${ }^{54}$ This was enough for the court to conclude that the directors had acted in good faith, which, in turn, prevented the court from questioning whether they had exercised sufficient "prudence". ${ }^{55}$ The court then outlined a second, more stringent standard of review. It explained that the directors were also under an obligation to inquire into "any circumstance or transaction which ought to have been inquired into by the persons making [the challenged] purchase" and ascertained "every fact that was to be ascertained" in the circumstances. ${ }^{56}$ This is clearly a process-related inquiry that is to be distinguished from an assessment of the merits of the business decision. In Overend \& Gurney, no due-process failures had been alleged by the complaint and the court, accordingly, rejected any liability of the defendant directors for the decision to purchase the business.

Subsequent cases have not always been similarly clear in their differentiation of the two standards. ${ }^{57}$ Nevertheless, where directors were found liable, this was generally (albeit not always ${ }^{58}$ ) because they were not sufficiently well informed, ${ }^{59}$ unquestioningly and uncritically complied with instructions and accepted information given by a corporate insider who engaged

\footnotetext{
52 "Success of the company" is the formulation used in s. 172(1) Companies Act 2006, which codifies the common law duty to act in good faith in the interest of the company.

${ }^{53}$ Overend \& Gurney v Gibb (1871-72) L.R. 5 H.L. 480 at 493.

${ }^{54} \mathrm{Id}$. at 493-94.

${ }^{55}$ See the quote from Overend \& Gurney supra in the text after note 48 .

${ }^{56}$ (1871-72) L.R. 5 H.L. at 495.

${ }^{57}$ This holds, in particular, for City Equitable, supra note 32 and accompanying text. See also KERSHAW, supra note 2, at 257-63, for a discussion of the influence that City Equitable had on corporate law scholarship and policy debates in the UK before the duty of care was codified in 2006 (arguing that City Equitable sowed "dissonance and confusion about the scope of the care standard", $i d$. at 263).

${ }^{58}$ See Roberts v Frohlich [2012] B.C.C. 407.

${ }^{59}$ See, e.g., Re D'Jan of London Ltd [1993] B.C.C. 646; Raithatha v Baig [2017] EWHC 2059.
} 
in fraudulent activity, ${ }^{60}$ had failed to ensure that internal reporting and control systems worked effectively, ${ }^{61}$ or had remained completely inactive. ${ }^{62}$ Furthermore, the process-related nature of the duty is evidenced by the fact that directors are less likely to be held liable for a breach of the duty of care if they take certain procedural precautions, such as obtaining expert advice. ${ }^{63}$

A more explicit delineation of an area of protected business judgement and a more formal distinction between a standard of conduct and a standard of review can be found in the United States. This chapter will focus on Delaware law, where the courts began to grapple with the problem of determining the standard of review applicable to business decisions in the 1920s. In a string of decisions, the Delaware courts established the rule that directors were presumed to exercise their business judgment bona fide and in the best interest of the company. ${ }^{64}$ Further, they held that the presumption did not apply if the directors were either interested in the challenged transaction ${ }^{65}$ or the circumstances of the transaction (for example the price paid for the assets of a corporation) were "so manifestly unfair as to indicate fraud" ${ }^{66}$ The latter was the case if the directors' actions were "so unreasonable as to be removed entirely from the realm of the exercise of honest and sound business judgment." $" 67$ These decisions relied on older, non-Delaware precedents that had sketched an area of business dealings - typically characterized, as a minimum, by the absence of fraud or bad faith, illegality, and conflicts of interest - that was regarded to be beyond judicial control. ${ }^{68}$ Similar to the reasoning of the House of Lords in Overend \& Gurney, the rationale given for such judicial restraint was that intervening in "[q]uestions of policy of management", which were left to the honest decision

\footnotetext{
${ }^{60}$ Weavering Capital (UK) Ltd v Dabhia [2013] EWCA Civ. 71.

${ }^{61}$ Re Barings plc and others (No 5) [1999] 1 BCLC 433.

${ }^{62}$ Lexi Holdings Plc v Luqman [2007] EWHC 2652.

${ }^{63}$ KERSHAW, supra note 2, at 280-81.

${ }^{64}$ Allied Chemical \& Dye Corporation v. Steel \& Tube Co. of America, 122 A. 142 (Del. Ch. 1923) (speaking of "[a] presumption which the law would ordinarily accord in favor of the fairness of [the] official acts [of directors]" (i.e. their business judgment), id. at 146).

${ }^{65} \mathrm{Id}$. at 146.

${ }^{66}$ Robinson v. Pittsburgh Oil Refining Corporation, 126 A. 46, 48 (Del. Ch. 1924).

${ }^{67} I d$. at 49.

${ }^{68}$ For example, Allied Chemical \& Dye Corporation v. Steel \& Tube Co. of America, 120 A. 486, 493 (Del. Ch. 1923), relied on the New Jersey case Hodge v. United States Steel Corp., 64 N.J. Eq. 807 (N.J. Ct. Err. \& App. 1903)
} 
of the directors, would amount to "substitut[ing] the judgment and discretion of others in the place of those determined on by the scheme of incorporation". ${ }^{69}$

In the first decades of its development, the Delaware approach was not yet known under the name "business judgment rule", and the precise contours of the rule were not yet well established. ${ }^{70}$ Two decisions of the Delaware Supreme Court from the first half of the 1980s gave the business judgment rule its modern form: Zapata Corp v. Maldonado ${ }^{71}$ and Aronson v. Lewis. ${ }^{72}$ In Aronson, the Supreme Court described the business judgement rule as "a presumption that in making a business decision the directors of a corporation acted on an informed basis, in good faith and in the honest belief that the action taken was in the best interests of the company". ${ }^{73}$ Furthermore, the protections of the business judgment rule "can only be claimed by disinterested directors ... [T]his means that directors can neither appear on both sides of a transaction nor expect to derive any personal financial benefit from it in the sense of self-dealing, as opposed to a benefit which devolves upon the corporation or all stockholders generally." 74 The burden is on the plaintiff to rebut the presumption, in which case the burden of proof shifts (generally ${ }^{75}$ ) to the defendant director to show the entire fairness of the challenged decision. ${ }^{76}$ On the other hand, if the three conditions-acting on an informed basis, in good faith, and without a conflict of interest - are met, the courts will not engage in a review of the quality of the business decision (with one very limited exception, the so-called waste claim or irrationality review ${ }^{77}$ ).

${ }^{69}$ Ellerman, 49 N.J. Eq. at 232. A similar explanation is given by Hodge, 64 N.J. Eq. at 812.

${ }^{70}$ The diffusion of the term "business judgment rule" is traced by KERSHAw, supra note 2, at 80-81 (identifying Nadler v. Bethlehem Steel Corp., 154 A.2d 146 (Del. Ch. 1959), as the first case employing the term.

71430 A.2d 779 (Del. 1981).

72473 A.2d 805 (Del. 1984).

${ }^{73} \mathrm{Id}$. at 812.

${ }^{74} I d$.

${ }^{75}$ Unless a conflict of interest has been "cleansed" pursuant to DeL. GeN. CoRP. LAW, § 144.

${ }^{76}$ In re Walt Disney Co. Derivative Litigation, 907 A.2d 693, 747 (Del. Ch. 2005).

${ }^{77}$ For a definition of waste, see In re Walt Disney Co. Derivative Litigation, 906 A.2d 27 (Del. 2006): “To recover on a claim of corporate waste, the plaintiffs must shoulder the burden of proving that the exchange was 'so one sided that no business person of ordinary, sound judgment could conclude that the corporation has received adequate consideration.' A claim of waste will arise only in the rare, 'unconscionable case where directors irrationally squander or give away corporate assets.' This onerous standard for waste is a corollary of the proposition that where business judgment presumptions are applicable, the board's decision will be upheld unless it cannot be 'attributed to any rational business purpose."' $I d$. at 74 (footnotes omitted). 
This basic operational framework of the business judgment rule has remained in place, although some of the conditions on which the presumption is based have shifted since Aronson. Importantly, while Aronson identified the applicable standard of care on which director liability was predicated as a gross negligence standard, ${ }^{78}$ the duty-of-care limb of the presumption (that is, the requirement to act on an informed basis) has become all but irrelevant in the wake of the controversial Delaware Supreme Court decision of Smith v Van Gorkom. ${ }^{79}$ First, the Delaware courts interpret gross negligence in the corporate context in a demanding manner that conflates rationality, bad faith and gross negligence. ${ }^{80}$ They define gross negligence as a "reckless indifference to or a deliberate disregard of the whole body of stockholders", ${ }^{81}$ involving actions "without the bounds of reason", ${ }^{82}$ or "a wide disparity between the process the directors used ... and that which would have been rational." 83 Second, in order to counteract the risk that corporations incorporate elsewhere to evade the heightened risk of liability suggested by Van Gorkom, the Delaware legislature included a provision in the Delaware General Corporation Law enabling companies to exclude liability of a director for monetary damages for a breach of the duty of care, provided the director did not act in bad faith.$^{84}$ Furthermore, subsequent decisions subsumed good faith under the duty of loyalty. Lack of good faith does not, by itself, establish liability for a breach of a fiduciary duty. ${ }^{85}$ Rather, bad faith may be, in some circumstances, a necessary condition for liability, and where it is, liability may then arise as a result of a breach of the duty of loyalty. ${ }^{86}$ Importantly, this has been held to be the case where director oversight liability is concerned. ${ }^{87}$ As a consequence, under Delaware law, qualitatively different conduct gives rise to liability for director action and failure to act. The leading case

\footnotetext{
78473 A. 2 d at 812 .

79488 A.2d 858 (Del. 1985).

${ }^{80}$ William T. Allen, Jack B. Jacobs \& Leo E. Strine, Realigning The Standard Of Review Of Director Due Care With Delaware Public Policy: A Critique Of Van Gorkom And Its Progeny As a Standard Of Review Problem, 96 Nw. U. L. REV. 449, 453 (2002).

${ }^{81}$ Tomczak v. Morton Thiokol, Inc., $1990 \mathrm{WL}$ 42607, at 12 (Del. Ch. 1990) (quoting Allaun v. Consolidated Oil Co., 147 A. 257, 261 (Del. Ch. 1929), and Gimbel v. Signal Companies, Inc., 316 A.2d 599, 615 (Del. Ch. 1974)); In re Walt Disney Co. Derivative Litigation, 907 A.2d 693, 750 (Del. Ch. 2005).

${ }^{82} I d$.

${ }^{83}$ Guttman v. Huang, 823 A.2d 492, 507 n. 39 (Del. Ch. 2003)

${ }^{84}$ Del. Gen. Corp. LaW, § 102(b)(7).

${ }^{85}$ Stone v. Ritter, 911 A.2d 362, 370 (Del. 2006).

${ }^{86} I d$.

${ }^{87} I d$. at 369.
} 
on oversight liability, Caremark, ${ }^{88}$ held that lack of good faith as a necessary condition for director oversight liability required "a sustained or systematic failure of the board to exercise oversight — such as an utter failure to attempt to assure a reasonable information and reporting system exists". ${ }^{89}$ This is, as the Court of Chancery noted in Caremark, "a demanding test of liability", but it was thought to be in the economic interest of the shareholders. ${ }^{90} \mathrm{We}$ will come back to this rationale in section 3.2 below.

Disregarding the separate standard of review for oversight liability, Delaware and UK law operate largely in parallel, in spite of the absence of an explicit business judgement rule in the UK. The quality of a business decision is shielded from judicial review in both jurisdictions unless the plaintiff can show bad faith. Lack of good faith will lead to liability under the further conditions of section 172 Companies Act 2006 in the UK and the entire fairness test in Delaware. The process of decision-making is ostensibly assessed against different standards of conduct: ordinary negligence (and heightened behavioural expectations in the case of special knowledge, skill or experience) in the UK and gross negligence, interpreted as recklessness or irrationality, in Delaware. However, it has been observed that British courts apply the objective limb of section 174(2) Companies Act 2006 so restrictively, and perform a skills adjustment pursuant to the subjective limb of the provision so reluctantly, that the standard of care is, in practice, close to the gross negligence standard of US jurisdictions..$^{91}$

The deployment of a good faith standard to review the quality of business decisions is less common in civil law jurisdictions, although the risk of liability is often not higher (and typically lower) than in the United States and in Britain, mostly for procedural reasons. ${ }^{92}$ A good example of the less well developed distinction between decision-making process and decision quality (and indeed between the duty of care and the duty of loyalty) is France, where the notion of the company's interest (l'intérêt social) guides the courts' assessment of liability for management mistakes. ${ }^{93}$ Directors are responsible for all acts or omissions that are contrary to

\footnotetext{
${ }^{88}$ In re Caremark Intern. Inc. Derivative Litigation, 698 A.2d 959 (Del. Ch. 1996).

${ }^{89}$ Id. at 971.

${ }^{90} I d$.

${ }^{91}$ KERSHAW, supra note 2, at 281.

92 Carsten Gerner-Beuerle \& Edmund-Philipp Schuster, The Evolving Structure of Directors' Duties in Europe, 15 EBOR 191, 214-22 (2014).

${ }^{93}$ See supra, notes 31, 44-45 and accompanying text. On the conflation of the duties of care and loyalty in French corporate law, see also GERNER-BEUERLE \& SCHILLIG, supra note 24, 574-75.
} 
the interests of the company. ${ }^{94}$ The infusion of considerations of the company's interest into the duty of care, something that, as we have seen, would be a matter for section 172 Companies Act 2006 in the UK, naturally invited the French courts to review not only the process of director decision-making, but also the quality of their decisions. Examples of management mistakes that gave rise to liability, accordingly, include transactions that were excessively risky, for example the ill-advised expansion of business operations without proper financing, ${ }^{95}$ the distribution of extraordinary dividends financed out of reserves during a time of contracting business operations, ${ }^{96}$ and the granting of excessive executive compensation. ${ }^{97}$

Notwithstanding these examples, courts in many civil law jurisdictions exhibit restraint in reviewing good-faith business decisions. ${ }^{98}$ Such restraint may be informal, in the sense of an acknowledgement that directors must be allowed to take risks inherent in economic activity and, hence, should benefit from an area of discretion that will not be fully reviewed by the courts, ${ }^{99}$ or formalised as a rule modelled after the Delaware business judgment rule. As mentioned, the latter approach is increasingly common, and business judgment rules similar to the Delaware rule can now be found in seven Member States of the EU belonging to the civil law tradition. ${ }^{100}$ Similar to Delaware law, the continental European variants of the business judgment rule apply if several threshold conditions are satisfied, which typically include the requirement that the challenged business decision was based on appropriate information, there was no conflict of interest, and the defendant director reasonably believed that the decision was in the best interest of the company. ${ }^{101}$

In the following paragraphs, we will examine the German version of the business judgment rule in more detail, which was the first such rule adopted in Europe in $2005^{102}$ and which will

\footnotetext{
${ }^{94}$ Jean-Paul Valuet \& Alain Lienhard, CODE DES SocIÉTÉs (34th ed. 2018), Com. Art. L225-251, Commentaire, I. Principe.

${ }^{95}$ Cass. com., 3 January 1995 (Nasa Electronique), Bull. Joly Sociétés 1995, p. 432, note A. Couret.

${ }^{96}$ Cass. com., 25 October 2011 (Sté Sorim), Bull. Joly Sociétés 2012, p. 243, note D. Poracchia.

${ }^{97}$ CA Rennes, 13 December 1995, Droit des sociétés 1996, $n^{\circ} 195$, note Y. Chaput.

${ }^{98}$ For a more detailed discussion, including references, see Gerner-Beuerle \& Schuster, supra note 92, 205-6.

${ }^{99} I d$. at 205.

${ }^{100}$ Supra note 6.

${ }^{101}$ See Gerner-Beuerle \& Schuster, supra note 92, at 205, for references.

102 GESETZ ZUR UNTERNEHMENSINTEGRITÄT UND MODERNISIERUNG DES ANFECHTUNGSRECHTS (UMAG) [Law on Corporate Integrity and Modernization of the Action of Annulment] of 22 September 2005, BGBl I 2005, p. 2802, Art 1, no. 1a. The codified business judgment rule, in turn, is based on a decision of the Bundesgerichtshof
} 
form the basis for an assessment of the influence of narratives in section 3 below. The rule is laid down in $\S 93(1)$ and (2) Stock Corporation Act, which are here reproduced in relevant parts: $:^{103}$

(1) ... A management decision shall be deemed not to be a violation of this duty if the member of the management board reasonably believed that he acted in the best interest of the company and the decision was based on appropriate information....

(2) Members of the management board who violate their duties shall be jointly and severally liable to the company for the resulting damage. They shall bear the burden of proving that they exercised the care of a diligent and conscientious manager. ...

The German business judgment rule applies if the following threshold conditions are met: (1) The defendant director must have acted in the best interest of the company ${ }^{104}$ and (2) the decision was based on appropriate information. ${ }^{105}$ Furthermore, even though not explicitly mentioned, because it was considered to be self-evident, challenged conduct is only protected by the business judgment rule if (3) it is not tainted by bad faith and (4) there is no conflict of interest. ${ }^{106}$ The director bears the burden of proving that these conditions are met, since the general allocation of the burden of proof pursuant to $\S 93(2)$, sentence 2 also applies to the threshold conditions.

On a cursory reading, the German business judgment rule follows closely its Delaware counterpart. The three prerequisites of the Delaware business judgment rule-duty of care, loyalty, and good faith — are all present. In two respects, the German version is more stringent (from the perspective of the director): In addition to the three conditions just mentioned, a director must also have reasonably believed that he or she acted in the best interest of the

[Federal Court of Justice] of 1997, BGHZ 135, 244 (ARAG/Garmenbeck), which adopted principles resembling the business judgment rule.

103 The translation is from GERNER-BEUERLE \& SCHILLIG, supra note 24, 506-7. AKTG, § 93(1), second sentence codifies the business judgment rule, and $\S 93(2)$ allocates the burden of proof.

104 Business decisions are in the best interest of the company if they "further the long-run profitability and competitiveness of the company and its products or services”, BT-DRS. 15/5092, p. 11.

${ }^{105}$ What is appropriate depends on the available time, potential market pressures, the importance of the decision for the company, and generally accepted views of what constitutes good managerial practice, BT-DRS. 15/5092, p. 12.

${ }^{106} I d$., at 11 . 
company. Furthermore, the burden of proof is on the director, whereas the plaintiff has to rebut the "presumptions" of the business judgment rule in Delaware. In two other respects, it is more lenient: The business judgment rule applies if the defendant director could reasonably assume that the threshold conditions of the rule were satisfied. Thus, the law does not provide for a negligence or gross negligence standard, but asks whether the director's subjective assessment was reasonable in light of the circumstances of the case. ${ }^{107}$ Second, if the conduct of a director is protected by the German business judgment rule, it will not be reviewed any further by the court. In this sense, the presumption of compliance with the duty of care that is established by the business judgment rule is non-rebuttable. In the US, on the other hand, courts will engage in a limited substantive review of well-informed business decisions adopted in good faith and without a conflict of interest and inquire whether a decision was "irrational" or constituted a "waste of corporate assets". ${ }^{108}$ However, whether these differences are of any consequence may be doubted. The waste claim plays virtually no role in practice and the benchmark of "reasonable belief" under German law is similar to the standard of care that applies in Delaware if the restrictive interpretation of gross negligence by the courts and the possibility to limit liability to bad faith in the certificate of incorporation are taken into account. ${ }^{109}$ Therefore, in terms of substance (disregarding procedural questions such as the allocation of the burden of proof), it is difficult to hold that there is a meaningful difference between the Delaware and German business judgment rules. However, an analysis not only of the codified German rule, but also its application by the courts, may lead to a different conclusion. We turn to this question next.

\section{Local narratives and the multiplicity of meaning: A comparison of the business judgment rule in Delaware and Germany}

\section{$3.1 \quad$ Multiplicity of meaning}

The multiplicity of meaning potentially inherent in similarly formulated legal institutions can be illustrated with the business judgment rule cases brought in the wake of the global financial crisis in Delaware and Germany. These cases concerned the liability of executive and non-

\footnotetext{
${ }^{107}$ For example, the assessment is unreasonable where a director "misjudges the risks associated with a managerial decision in an entirely irresponsible way", $i d$.

${ }^{108}$ Supra, note 77 and accompanying text.

${ }^{109}$ Supra, note 80-84 and accompanying text.
} 
executive directors of financial institutions who had accepted excessive exposures to the subprime mortgage market and caused significant losses to their institutions, which necessitated, in some cases, a bailout by the government. ${ }^{110}$ The decisions present useful case studies, because in most of the cases, there was no evidence of bad faith, ${ }^{111}$ and the claim that the defendant directors had breached their duty of care rested mainly on the allegation that they had engaged in excessive risk-taking and ignored warning signs that the CDO market was overheating.

In Delaware, the first case addressing investment decisions made in the lead-up to the subprime mortgage crisis was In re Citigroup Inc. Shareholder Derivative Litigation, ${ }^{112}$ decided by the Delaware Court of Chancery in 2009. The plaintiffs claimed that the defendant directors and officers of Citigroup had breached their fiduciary duties by investing in collateralized debt obligations (CDOs) and accumulating an exposure of $\$ 55$ billion to the subprime mortgage market. The plaintiffs further alleged that the directors continued to invest in spite of mounting warning signs that market conditions were worsening, such as the bankruptcy of subprime lenders or the downgrade of mortgage backed securities by Moody's and Standard and Poor's. ${ }^{113}$ Applying the Caremark standard for directorial neglect (here the failure to monitor risk exposure ${ }^{114}$ ), the court observed: ${ }^{115}$

To the extent the Court allows shareholder plaintiffs to succeed on a theory that a director is liable for a failure to monitor business risk, the Court risks undermining the well settled policy of Delaware law by inviting Courts to perform a hindsight evaluation of the reasonableness or prudence of directors' business decisions. Risk has been defined as the chance that a return on an

\footnotetext{
110 The most important cases are In re Citigroup Inc. Shareholder Derivative Litigation, 964 A.2d 106 (Del. Ch. 2009); In re American Intern. Group, Inc., 965 A.2d 763 (Del. Ch. 2009); In re Goldman Sachs Group, Inc. Shareholder Litigation, 2011 WL 4826104 (Del. Ch. 2011); Oberlandesgericht [Higher Regional Court] Düsseldorf, decision of 9 December 2009, 6 W 45/09, BeckRS 2010, 532 (IKB) (for Germany).

${ }^{111}$ With the exception of American Intern. Group., where the court found evidence of "pervasive, diverse, and substantial financial fraud involving managers at the highest levels of AIG", 965 A.2d at 776. Consequently, the court held that it was inferable that the defendants "knew that AIG was engaging in illegal conduct", and hence acted in bad faith, 965 A.2d at 782 .

112964 A.2d 106 (Del. Ch. 2009).

113964 A.2d at 115.

114 The court expressed some doubts as to whether this was indeed a Caremark claim, or the essence of the plaintiffs' pleadings was rather to hold the defendant directors accountable for business decisions, namely the bank's investment strategy, see the discussion 964 A.2d at 123-24. The court nevertheless engaged in a substantive analysis of the merits of the Caremark claim, as presented by the plaintiffs.
}

115964 A.2d at 126-31. 
investment will be different than expected. The essence of the business judgment of managers and directors is deciding how the company will evaluate the trade-off between risk and return. Businesses - and particularly financial institutions - make returns by taking on risk; a company or investor that is willing to take on more risk can earn a higher return. Thus, in almost any business transaction, the parties go into the deal with the knowledge that, even if they have evaluated the situation correctly, the return could be different than they expected. It is almost impossible for a court, in hindsight, to determine whether the directors of a company properly evaluated risk and thus made the "right" business decision. ...

It is well established that the mere fact that a company takes on business risk and suffers losses - even catastrophic losses - does not evidence misconduct, and without more, is not a basis for personal director liability. That there were signs in the market that reflected worsening conditions and suggested that conditions may deteriorate even further is not an invitation for this Court to disregard the presumptions of the business judgment rule and conclude that the directors are liable because they did not properly evaluate business risk. ...

The excerpt bears the hallmarks of what can be called an economic narrative that substantiates many recent duty of care decisions in Delaware. The court refers to hindsight bias to justify judicial deference and employs a finance-theory inspired (albeit somewhat non-technical) definition of risk and the risk-return trade-off. The excerpt also underlines the force of the protections of the business judgment rule. If the rule applies, which means in the case of a Caremark claim ${ }^{116}$ that the plaintiffs did not succeed in establishing bad faith, no liability will attach to the directors' decisions, even decisions that entail "catastrophic losses". In Citigroup, accordingly, all claims against the directors based on the CDO transactions failed.

A similar line of reasoning can be observed in a second high-profile case that dealt with excessive risk taking during the global financial crisis, In re Goldman Sachs Group, Inc. Shareholder Litigation. ${ }^{117}$ In this case, the plaintiffs advanced, again to no avail, the Caremark claim from a different angle. They alleged that Goldman's compensation structure, which

\footnotetext{
${ }^{116}$ Or if the company has made use of DEL. GEN. CORP. LAW, § 102(b)(7).

1172011 WL 4826104 (Del. Ch. 2011).
} 
linked compensation to the company's performance and awarded management a significant proportion of net revenue, ${ }^{118}$ gave an incentive to engage in risky trading practices and maximise short-term profits. It thus led, in the words of the plaintiffs, to "unethical and illegal practices", and the directors "failed to satisfy their oversight responsibilities with regard to those practices." 119 The court examined the plaintiffs' claim under two aspects: the "original" Caremark claim, which involved the failure to oversee conduct that led to violations of the law, and the Citigroup version of the claim, which is in some sense a product of the subprime mortgage crisis in that it seeks to hold directors responsible for not identifying and addressing business risks that lead to substantial losses. The original Caremark claim failed because the plaintiffs' identification of one possibly illegal trade, Goldman's Abacus 2007-AC1 transaction, did not cross the threshold of "a sustained or systematic failure of the board to exercise oversight" that had been established by Caremark. ${ }^{120}$ As regards the "business risk" version of the Caremark claim, the court reiterated that such a claim could only succeed if the plaintiffs showed a conscious failure to implement any sort of risk monitoring system. ${ }^{121}$ In the case at hand, in contrast, the plaintiffs had based their claim on arguments that would have required a "substantive evaluation by a court of a board's determination of the appropriate amount of risk ... [that is, a decision that] plainly involve[s] business judgment", which was outside the remit of a court. ${ }^{122}$

These holdings are diametrically opposed to the treatment of the problem of excessive risktaking in Germany. The case that discusses the problem in greatest detail, a decision of the Higher Regional Court Düsseldorf from 2009, $I K B$, concerned the near-insolvency of a German lender that focussed on the provision of loans to medium-sized enterprises, IKB Deutsche

\footnotetext{
${ }^{118}$ In the years 2007-2009, total compensation paid by Goldman to its employees ranged between 36 per cent and 48 per cent of total net revenue. 2011 WL 4826104 at 3.

1192011 WL 4826104 at 2. The plaintiffs also alleged that the directors breached their duty of care by approving the compensation structure and that the payments under the compensation structure constituted corporate waste. These two claims also failed.

${ }^{120}$ See 2011 WL 4826104 at 21.

121 The court emphasised that plaintiffs would be unlikely to succeed on a "business risk" Caremark claim, requiring that "the plaintiff would essentially have to show that the board consciously failed to implement any sort of risk monitoring system or, having implemented such a system, consciously disregarded red flags signaling that the company's employees were taking facially improper, and not just ex-post ill-advised or even bone-headed, business risks. Such bad-faith indifference would be formidably difficult to prove." 2011 WL 4826104 at 22, fn. 217.
}

1222011 WL 4826104 at 22. 
Industriebank. ${ }^{123}$ Owing to its investments in collateralised debt obligations backed by US subprime mortgages, IKB suffered heavy losses in the aftermath of the financial crisis and had to be bailed out by the German government. Minority shareholders requested the appointment of an auditor to investigate potential breaches of the duty of care, arguing, inter alia, that the directors had violated their duties by creating an exposure to the subprime CDO market that had amounted at one point to 47 per cent of the bank's total business volume, leading to excessive, undiversified risk. They further alleged that the supervisory board had failed to monitor the management board's investment strategy properly and had not addressed the bank's skewed risk exposure. On appeal, the Higher Regional Court found that the members of both the management board and the supervisory board were liable for a breach of the duty of care. The court's arguments deserve close attention. First, because of the difficulties in assessing the risks associated with multi-layered structured finance products, the court doubted whether directors could ever be fully informed when investing in securitized product. ${ }^{124}$ Second, irrespective of any failure to be fully informed, the court held that "[n]o management board acts in compliance with the duty of care if they take risks that will render the company insolvent if they materialise" and relate to "foreign, largely unknown and ultimately uncontrollable securities". ${ }^{125}$ The court did not explicitly identify the threshold condition on which it based the conclusion that the protections of the business judgment rule did not apply. However, it stressed that the "knowing" acceptance of "excessive risks" 126 led, in the present case, to a breach of duties, thus implying that the business judgment rule was inoperable because the directors could not have reasonably believed that they were acting in the best interest of the company, or they had acted in bad faith. Given that the directors were not protected by the business judgment rule, the court went on to discuss whether their investment decisions were compatible with the actions of a prudent and conscientious manager and concluded that they were not, because the directors had failed to follow basic principles of

\footnotetext{
${ }^{123}$ Oberlandesgericht [Higher Regional Court] Düsseldorf, decision of 9 December 2009, 6 W 45/09, BeckRS 2010, 532.

${ }^{124}$ BeckRS 2010, 532, at II 2 b) bb) aaa) (1).

${ }^{125}$ Id. at II 2 b) bb) bbb). Translation from GERNER-BeUERLE \& SCHILLIG, supra note 24, at 518.

${ }^{126}$ BeckRS 2010, 532, at II 2 b) bb): "[I] it is reasonable to assume that the respondent's management board violated its duties grossly because the board did not act on the basis of sufficient information and knowingly took excessive risks, in particular concentration risks." Translation from GERNER-BEUERLE \& SCHILLIG, supra note 24, at 517.
} 
prudent banking, such as diversifying the investment portfolio sufficiently well and ensuring that concentration risk was manageable. ${ }^{127}$

Of course, there are a number of relevant factual differences between $I K B$ on the one hand and Citigroup and Goldman Sachs on the other. Most importantly, IKB is a medium-sized bank with clearly specified objects, notably the purpose of serving the financing needs of mediumsized enterprises. It may therefore be speculated whether $I K B$ would have been decided differently from Citigroup and Goldman Sachs in Delaware. Nevertheless, the difference in outcome in the three cases is striking, and, importantly, it is not related to any of the legal differences in the formulation of the German and Delaware business judgment rules identified above, ${ }^{128}$ but to elements identical in the two jurisdictions: the fact that the business judgment rule does not protect conduct in violation of the law or the articles or carried out in bad faith. Consequently, on the assumption that the factual differences are not sufficient in explaining the diverging outcomes, it can be concluded that the interpretive approaches of the two courts render the textual identity of most elements of the German and Delaware business judgment rules, at least in these particular cases, irrelevant. The next section offers a tentative explanation of why the interpretive approaches of the courts may differ.

\subsection{Local narratives}

The court in Citigroup, as in many other recent duty of care decisions, embraced an economic narrative to justify the understanding of the business judgment rule underlying the judgment. The perhaps most eloquent example of this economic narrative in Delaware is Chancellor Allen's opinion in In re Caremark Intern. Inc. Derivative Litigation, ${ }^{129}$ where the Chancellor qualified earlier case law ${ }^{130}$ to apply the protections of the business judgment rule also to director neglect or failure to monitor, and indeed extended the protections in comparison with

\footnotetext{
${ }^{127}$ BeckRS 2010, 532, at II 2 b) bb) bbb).

${ }^{128}$ Supra, text to notes $107-108$.

129698 A.2d 959 (Del. Ch. 1996).

${ }^{130}$ See, e.g., Rabkin v. Philip A. Hunt Chemical Corp., 13 Del. J. Corp. L. 1210 (Del. Ch. 1987) (holding that ordinary negligence is the appropriate standard of liability in director neglect claims).
} 
cases involving director action. ${ }^{131}$ In the opinion of the Chancellor, the policy rationale of the business judgment could be summarised as follows: $:^{132}$

What should be understood, but may not widely be understood by courts or commentators who are not often required to face such questions, is that compliance with a director's duty of care can never appropriately be judicially determined by reference to the content of the board decision that leads to a corporate loss, apart from consideration of the good faith or rationality of the process employed. That is, whether a judge or jury considering the matter after the fact, believes a decision substantively wrong, or degrees of wrong extending through "stupid" to "egregious" or "irrational", provides no ground for director liability, so long as the court determines that the process employed was either rational or employed in a good faith effort to advance corporate interests. To employ a different rule-one that permitted an "objective" evaluation of the decision-would expose directors to substantive second guessing by ill-equipped judges or juries, which would, in the long-run, be injurious to investor interests. Thus, the business judgment rule is process oriented and informed by a deep respect for all good faith board decisions.

Noteworthy is also the following footnote from the above excerpt: ${ }^{133}$

The vocabulary of negligence while often employed, ... is not well-suited to judicial review of board attentiveness, ... especially if one attempts to look to the substance of the decision as any evidence of possible "negligence." Where review of board functioning is involved, courts leave behind as a relevant point of reference the decisions of the hypothetical "reasonable person", who typically supplies the test for negligence liability. It is doubtful that we want business men and women to be encouraged to make decisions as hypothetical persons of ordinary judgment and prudence might. The corporate form gets its utility in large part from its ability to allow diversified investors to accept greater investment risk. If those in charge of the corporation are to be adjudged personally liable for losses on the basis of a substantive judgment based upon

\footnotetext{
${ }^{131}$ Supra, text to notes 88-89.

132 Caremark, 698 A.2d at 967-68.

${ }^{133} I d$. at 967 , fn. 16.
} 
what persons of ordinary or average judgment and average risk assessment talent regard as "prudent" "sensible" or even "rational", such persons will have a strong incentive at the margin to authorize less risky investment projects.

Similar rationalizations of the business judgment rule, which adopt concepts of economic theory, behavioural economics and corporate finance, such as utility maximization, incentives, hindsight bias, risk aversion, diversification, or value of an investment project, can be found in an increasing number of decisions since the 1980s. ${ }^{134}$ The contrast in the style of judicial reasoning with the foundational decisions on the business judgment rule in Delaware is striking. Before the 1990s, not a single Delaware case discussed investor diversification in the context of the business judgment rule. ${ }^{135}$ In only one case, a decision from 1988, the Delaware Court of Chancery referred to the second-guessing of good-faith business decisions to argue that judicial intervention would discourage the socially efficient "allocation of assets and ... assumption of economic risk by those with [the] skill and information [to evaluate such risk]". ${ }^{136}$ Since 1996, the year in which Caremark was decided, ${ }^{137}$ economic reasoning as a justification for the business judgement rule has proliferated. The dangers of second-guessing good-faith business decisions were discussed in 55 business judgment rule cases, ${ }^{138}$ and the economic consequences of investor diversification in 17 cases. $^{139}$

This shift in the narrative underpinning the business judgment rule coincided with a transformation of the dominant approach in legal thought, initially in the United States, but later also in the UK and other countries, to conceptualising the business corporation and interpreting central elements of the regulatory framework governing the corporate economy,

\footnotetext{
${ }^{134}$ One of the earliest decisions using hindsight bias, risk aversion and portfolio theory to justify the business judgment rule, albeit not from a Delaware court, is Joy v. North, 692 F.2d 880 (2d Cir. 1982) (drawing heavily on a newly published law and finance textbook, William Klein, Business Organization and Finance (1980)).

135 According to a Westlaw search of all Delaware state cases using the search algorithm (diversif! /p investor!) \& "business judgment rule".

${ }^{136}$ Solash v. Telex Corp., 13 Del. J. Corp. L. 1250, 1262 (Del. Ch. 1988). The results were generated by a Westlaw search of all Delaware state cases using the search algorithm (hindsight risk +1 avers! second +1 guess!) \& "business judgment rule". In a number of further cases, the courts argued that it would be inappropriate to secondguess business decisions, without, however, considering the effects of such second-guessing on the risk attitudes of directors, see, e.g., Freedman v. Restaurant Associates Industries, Inc., 13 Del. J. Corp. L. 651 , 664 (Del. Ch. 1987); and Thompson v. Enstar Corp; Huffington v. Enstar Corp, 9 Del. J. Corp. L. 822 (Del. Ch. 1984).

${ }^{137}$ As well as Gagliardi v. TriFoods, quoted supra note Error! Bookmark not defined..

138 The results were generated by a Westlaw search of all Delaware state cases using the search algorithm (second +1 guess! /p "business judgment rule”) (not counting Caremark and Gagliardi v. TriFoods).

139 The results were generated by a Westlaw search of all Delaware state cases using the search algorithm (diversif! /p investor!) \& “business judgment rule” (not counting Caremark).
} 
such as shareholder rights, fiduciary duties, appraisal rights, takeover regulation, mandatory disclosure in financial markets, and the regulation of insider dealing. This new approach, epitomized by the writings of Frank H. Easterbrook and Daniel R. Fischel, ${ }^{140}$ drew heavily on recent innovations in economic theory and financial economics in order to develop a theory of corporate law based on an efficiency calculus, sometimes simply referred to as "agency theory". ${ }^{141}$ It is not the goal of this contribution to establish causality between the normative proposals of agency theory and the outcomes of judicial decisions and reform initiatives by policy makers. The important point is that they have plausibly had an impact on the nature of the legal discourse, in particular the role that economic reasoning plays in this discourse.

This influence was absent in Germany, where the legal discourse has only very recently begun to absorb agency cost theory, and economic reasoning does not feature prominently in court decisions. Instead, in order to unearth a potential explanation for the different approach of the German courts, it is necessary to go back to the reforms of corporate law of 1884, which, as discussed above, introduced important changes to the formulation of the duty of care and established a regulatory framework for the public stock corporation that is, in its general tenets, still in force today. ${ }^{142}$ The reforms have to be seen against the backdrop of the stock exchange crash, in response to which they were adopted. In the years before the crash, the incorporation regime in Germany had been liberalized and the law had, for the first time, allowed incorporation by simple registration. ${ }^{143}$ The liberalization of the incorporation regime led to a dramatic increase in incorporations, including of many companies that were incorporated merely with a view to raising funds for the promoters, without having a viable business

\footnotetext{
${ }^{140}$ See, in particular, Frank H. EASterbrook \& DANiEl R. Fischel, THe ECONOMIC StrUCtURE OF Corporate LAW (1991).

${ }^{141}$ Important economic building blocks of the emerging agency theory in corporate law were the efficient market hypothesis, which posits (in its semi-strong form) that in efficient capital markets all publicly available information is incorporated quickly into securities prices (Eugene F. Fama, Efficient Capital Markets: A Review of Theory and Empirical Work, 25 J. FIN. 383 (1970)), the Coase-theorem, which holds that in the absence of transaction costs the initial allocation of rights is irrelevant because the parties will negotiate to bring about Paretoefficient outcomes (Ronald H. Coase, The Problem of Social Cost, 3 J.L. \& ECON. 1, 2-8 (1960)), and modern portfolio theory, which presents a framework for the design of an optimal portfolio of assets given a particular level of risk (or variance) (Harry Markowitz, Portfolio Selection, 7 J. Fin. 77 (1952)). These developments laid the groundwork for a conceptualisation of the business corporation built on agency costs, proposed first by the two economists Michael C. Jensen and William H. Meckling, Theory of the Firm: Managerial Behaviour, Agency Costs, and Ownership Structure, 3 J. FIN. ECON. 305 (1976), and then assimilated into corporate theory by Easterbrook, Fischel, and others.

${ }^{142}$ Supra, text to notes 27-28.

${ }^{143}$ GeSETZ, BETREFFEND Die KommanditgeSellschaften AUf AKTIEN UND DIE AKTIENGESELLSCHAFTEN [Act concerning limited partnerships by shares and joint stock corporations] of 11 June 1870, BGBl. NORDDT. BUND 1870, p. 375.
} 
model. ${ }^{144}$ In the crash, many of these companies, as well as a large number of financial institutions and other listed companies, became insolvent, the market capitalization of German stock corporations decreased by about $46 \%$, and the real economy contracted considerably, leaving both the public and policy makers deeply suspicious of speculative activity and capital markets more generally. ${ }^{145}$

The legislative memorandum that was published together with the draft law of 1884 reflected these sentiments. According to the memorandum, the reforms pursued a twofold policy goal: They sought to curtail speculative investments by "investors who are both credulous and avaricious ... have no personal relationship with the company, do not want to take part in business operations, reject any responsibility beyond their contribution, want to receive dividends that are as high as possible, and have the option of withdrawing from the company at any time by selling their shares". ${ }^{146}$ At the same time, the reforms were adopted with somewhat diffuse macroeconomic goals in mind. It was believed that the incorporation of a large number of companies gave rise to overproduction and the law should ensure that only socially useful firms were incorporated. ${ }^{147}$ However, the legislator also acknowledged that it could not be the role of the law to differentiate between economically productive and less productive uses of the corporate form. ${ }^{148}$ Instead of imposing some form of merit requirements, the legislator therefore focused on tightening the incorporation regime, curtailing access to the equity markets by small, potentially naïve and speculative investors, and limiting the influence of investors over the management of corporations. The centerpieces of the reform, accordingly, were the introduction of an onerous and costly incorporation regime characterized by high minimum legal capital requirements and stringent rules on capital contributions ${ }^{149}$ and a clearer

\footnotetext{
${ }^{144}$ For data and references, see Carsten Gerner-Beuerle, Law and Finance in Emerging Economies, 80 MODERN LAW REVIEW 265, 272-73 (2017).

${ }^{145}$ Rainer Gömmel, Entstehung und Entwicklung der Effektenbörsen im 19. Jahrhundert bis 1914 in DEUTSCHE BörsengesCHichte 153-155 (Hans Pohl ed., 1992).

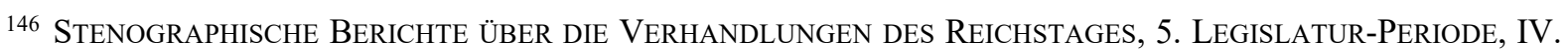
SESSION 1884 [Stenographic protocols of the proceedings of the Reichstag, $5^{\text {th }}$ parliamentary term, session IV 1884], vol. 3, document no. 21 (henceforth 'STENOGRAPHISCHE BERICHTE'), p. 241. Most of the document (except appendix B containing statistical information) is reprinted in WERNER SCHUBERT \& PETER HOMMELHOFF (EDS.), Hundert JAHRE MODERNES AKTIENRECHT: EINE SAMMLUNG VON TEXTEN UND QuelLEN ZUR AKTIENRECHTSREFORM 1884 MIT ZWEI EINFÜHRUNGEN 387-559 (1985). Page numbers here refer to the original Reichstag document.

${ }^{147}$ Id. See also the references in Werner Schubert, Die Entstehung des Aktiengesetzes vom 18. Juli 1884 in SCHUBERT \& HOMMELHOFF (EDS.), supra note 146, at 1, 49.

${ }^{148}$ STENOGRAPHISCHE BERICHTE, supra note 146, at 242.

${ }^{149}$ Most importantly, the minimum par value of shares was increased to 1,000 marks, ADHGB, Art 207a. The increase was intended to both prevent small savers from accessing the capital markets, because the legislator
} 
separation of the function and composition of the management board and supervisory board. ${ }^{150}$ The liability provisions, with their emphasis on a clearly defined, objective standard of care and reversal of the burden of proof reinforce the narrative of an untrammeled finance capitalism that took advantage of the impressionable retail investor and hence had to be reined in. As I have argued elsewhere, the legislative decisions made at this critical juncture determined not only the path of German corporate law, but, at least as a contributing factor, also the trajectory of financial development and the structure of the corporate economy in Germany, in particular by rendering equity capital more expensive than debt. ${ }^{151}$ It is not useful to speculate about the motives of the judges deciding $I K B$, but it is noteworthy that the decision is in line with a narrative that is characterized by a suspicion and distrust of finance capitalism, which justifies, in appropriate circumstances, a judicial review of socially harmful business decisions.

\section{Conclusion}

History matters. While the duty of care and, increasingly, the business judgment rule have diffused widely and exhibit a considerable degree of consistency across jurisdictions and legal families, similarly formulated rules may mean something very different in two legal systems that are shaped by different regulatory approaches, schools of thought, and historical experiences with the market economy, just as two differently formulated rules may mean something very similar. A case in point regarding the latter is the presence of a business judgment rule in Delaware, and the absence of such a rule in the UK. As case in point regarding the former is, again, the Delaware business judgment and its German counterpart. Two decades ago, judicial innovation and legislative intervention imported a slightly modified version of the Delaware business judgment rule into German law. However, the legal changes heralded only ostensibly a development towards convergence. The underlying narratives that determine the meaning of the two rules remained distinct-one shaped by considerations of economic efficiency and the other by a distrust of finance capitalism. The findings suggest that where

believed that they were not well placed to assess the value of equity securities and should place their savings in safe instruments, such as government bonds, and incentivize professional investors to participate more actively and with a longer-term horizon in the affairs of the company, given the less liquid market in equity securities, STENOGRAPHISCHE BERICHTE, supra note 146, at 245.

${ }^{150}$ ADHGB, as amended in 1884, Art 225a.

151 Gerner-Beuerle, supra note 144, at 289-93, 296-98. The precise effect of individual legal institutions on financial development is hotly contested. It is beyond the scope of this contribution to revisit the debate; for an overview, see $i d$. at 266-67. 
policy makers embrace foreign legal institutions, or supranational efforts are made to harmonize legal rules, it is important to be aware of the existence of local narratives and their impact on the law. 